Saudi Journal of Oral and Dental Research

Abbreviated Key Title: Saudi J Oral Dent Res

ISSN 2518-1300 (Print) |ISSN 2518-1297 (Online)

Scholars Middle East Publishers, Dubai, United Arab Emirates

Journal homepage: https://saudijournals.com/sjodr

Review Article

\title{
Injectable Gels in Endodontics: A Review
}

Dr. Surabhi Soumya, $\mathrm{PG}^{1 *}$, Dr. Abhay Sugriv Munde ${ }^{2}$, Dr. Izaz shaik, MDS, DMD ${ }^{3}$, Dr. Akriti Mahajan, MDS (Oral medicine and radiology $)^{4}$, Dr. Rahul VC Tiwari, OMFS, FOGS, PhD Scholar ${ }^{5}$, Dr. Heena Tiwari, BDS, PGDHHM ${ }^{6}$

${ }^{1}$ PG Trainee Dept of Conservative Dentistry and Endodontics, Kalinga Institute of Dental Sciences, Kiit University

${ }^{2}$ 2nd yr PG Student, Department of Conservative Dentistry \& Endodntics, Pandit Deendayal Upadhyay Dental College, Solapur, Maharashtra

${ }^{3}$ Student, Rutgers School of Dental Medicine, Newark, New Jersey, USA

${ }^{4}$ Private Consultant, Jammu and Kashmir, India

${ }^{5}$ Dept of OMFS, Narsinbhai Patel Dental College and Hospital, Sankalchand Patel University, Visnagar, Gujarat, India

${ }^{6}$ Ex-Government Dental Surgeon, Kondagaon, Chhattisgarh, India

DOI: $10.36348 /$ sjodr.2020.v05i09.005 $\quad$ | Received: 22.08.2020 | Accepted: 30.08 .2020 | Published: 03.09 .2020

*Corresponding author: Dr. Surabhi Soumya

\section{Abstract}

The field of endodontics and the success of endodontic procedures both heavily rely on effective chemo-mechanical debridement and disinfection of the contaminated root canal system. While the mechanical debridement involves removal of tissue/debris and enlargement of the canal with endodontic instrumentation (files), the chemical debridement relies heavily on irrigants and intra-canal medicaments. Current endodontic irrigation and intra-canal medications (such as $5.25 \%$ sodium hypochlorite and calcium hydroxide) used in endodontics do not provide adequate and complete bacterial eradication during endodontic treatment. It has been suggested that both sodium hypochlorite and calcium hydroxide are irritating and cytotoxic to dental and periodontal tissues if these materials reach beyond the confines of pulp canal space. A new material and method for disinfection is desirable.

Keywords: Gels, Injectable, Endodontics.

Copyright @ 2020: This is an open-access article distributed under the terms of the Creative Commons Attribution license which permits unrestricted use, distribution, and reproduction in any medium for non-commercial use (NonCommercial, or CC-BY-NC) provided the original author and source are credited.

\section{INTRODUCTION}

The idea of using hydrogels as a scaffolding material has been recently implemented in the fields of tissue engineering, regenerative medicine, as well as some aspects of dentistry. The use of hydrogels in endodontics has been limited at this point. Carbon dots (a subclass of graphene quantum dots) are a novel material that was introduced in 2004. The use of this material has not been thus far considered for endodontic purposes. Combining carbon dots with a hydrogel network could allow a potential delivery vehicle to apply the material inside the prepared canal and execute the required biological functions as part of conventional or regenerative endodontic treatment.

\section{Conventional Endodontics and Irrigants}

Endodontics is a specialty within dentistry largely dedicated to the treatment of dental pulp pathology and periradicular diseases. Despite often presenting without symptoms, endodontic pathology is often caused by complex biofilm invasion into the pulp tissue, which can grow without appropriate dental treatment; as the disease process advances, biofilms become more resistant to treatment [1]. Root canal therapy (RCT) is a common procedure, which is performed to remove or reduce biofilm within the canal space and treat tooth-borne dental infections. When performed to an acceptable standard, nonsurgical RCT is highly successful with success rates ranging from $88 \%$ [2] to $96 \%$ [3]. Proper disinfection is crucial to an overall successful outcome of root canal therapy, since residual biofilm is known to cause most endodontic failures [1]. Multiple major obstacles exist when it comes to achieving complete cleaning of the canal system. These include the complexity of the root canal system, presence of numerous dentinal tubules in the roots, invasion of the tubules by microorganisms, formation of smear layer during instrumentation and presence of dentin as a tissue [4]. Torabinejad described properties of an ideal irrigant, which includes ability to disinfect and penetrate dentin and its tubules, offer long-term antibacterial effect (substantivity), remove the smear layer; it should also be nonantigenic, nontoxic and noncarcinogenic [4]. Additionally, it shouldn't interfere with sealing ability of obturation materials, be relatively inexpensive, convenient to apply, not cause tooth discoloration, be able to dissolve pulp tissue and inactivate endotoxins [4]. Currently, no single irrigant is able to accomplish all of these goals. 
Instead, a combination of multiple irrigants and medicaments is utilized for these tasks. Sodium hypochlorite is the most widely used irrigant today, with concentrations typically ranging from $0.5 \%$ to $5.25 \%$. The mechanism of this irrigant essentially relies on the ability of free chlorine ions to dissolve vital and necrotic tissue by breaking down proteins into amino acids [5]. Decreasing its concentration has been shown to decrease the antibacterial effect, while warming the solution or increasing the volume increases the effectiveness. While being highly advantageous in multiple clinical aspects, this irrigant is highly cytotoxic. Its extrusion into periradicular tissues has been shown to cause severe injury to the patient [6]. Additionally, sodium hypochlorite has been shown to be unable to destroy all endodontic bacterial species [7$10]$ is ineffective at removing E. faecalis from dentinal tubules [11], does not have the ability to remove smear layer [12] and causes unwanted dentin alteration and erosion [13, 14]. Due to all aforementioned disadvantages, the use of supplemental irrigation is advocated.

Additionally, the development of a more ideal irrigant is desired. Chlorhexidine gluconate has been used in dentistry for over 50 years in preventative dentistry and periodontal therapy due to its bactericidal and bacteriostatic properties [15]. Its major advantages have been attributed to its broad-spectrum antibacterial action, substantivity (sustained action) and low toxicity (5). This irrigant does have certain disadvantages. Chlorhexidine gluconate is unable to dissolve organic substances and necrotic tissue, remove smear layer and eradicate all bacteria $[16,17]$.

Finally, Basrani et al. have discovered and analyzed the presence of para-chloro-aniline precipitate, which is formed when chlorhexidine gluconate is mixed with even minute amounts of sodium hypochlorite [18]. It was proposed that this precipitate may not only be carcinogenic, but can also negatively impact the sealing abilities of endodontic sealers and obturation materials. Ethylenediamenetetraacetic acid (EDTA) has been introduced into endodontics to address the inability of other irrigants to remove smear layer. Specifically, EDTA removes the inorganic portion of the smear layer (4). An adjunct rinse with $\mathrm{NaOCl}$ after a 1-minute rinse with EDTA has been shown to effectively remove the organic portion of the smear layer (5). By itself, EDTA has been shown to have little or no antibacterial effect [19].

\section{One- versus Two-Appointment Protocol and Intracanal Medicaments}

The topic of performing root canal therapy in one- versus two-appointment protocol has been a controversial topic for clinicians for many years. The proponents of two-appointment procedure protocol argue that it is impossible to sufficiently lower the microbial load within the infected canal space to levels compatible with sufficient recovery. Sjögren and Trope assessed influence of bacterial infection on the outcome of treatment based on culturing at the time of obturation $[8,9]$. They found that canals with negative cultures yielded statistically significantly better outcomes compared to those with positive cultures (94\% versus $68 \%$ ) at 5 years. As a result, they concluded that canals "cannot be reliably achieved in a one-visit treatment because it is not possible to eradicate all infection from the root canal without the support of an interappointment antimicrobial dressing." A study by Nair arrived at similar conclusions [20], after finding that the complexity of root canal anatomical systems (particularly in mandibular first molars) and organization of bacterial biofilms in inaccessible areas does not allow for adequate disinfection of contaminated root canal spaces. On the other hand, many high level studies find no difference in the longterm outcomes of root canal therapy whether a single or multiple appointment protocol is used and regardless of the preoperative diagnosis $[21,22]$.

\section{Tissue Engineering, Scaffolds and Hydrogels}

The goals of tissue engineering include providing the affected diseased tissue with the ability to restore, maintain or improve its function. In various fields of medicine this is typically achieved with the use of scaffolds, which provides a 3-dimensional network for cells and tissues to organize and integrate [23]. In order to be considered a successful and effective scaffold, the material needs to be biocompatible, biodegradable, have mechanical properties consistent with the site of implantation, have structural ability to maintain 3-dimensional shape while allowing adequate nutrient diffusion and be cost effective to be commercially viable [23]. Scaffolds provide support for cell organization, proliferation, differentiation and vascularization [24]. As discussed in the above paragraphs, regenerative endodontic procedures currently utilize the tooth's dentin and blood clot as a scaffold in the root canal [25]. Multiple authors have discussed the use of protein-rich-plasma (PRP) for use as a scaffold in these cases [26]. Other scaffolds that have been considered include natural scaffolds such as collagen, hyaluronic acid, chitosan and chitin, as well as synthetic ones such as polycaprolactone, polylactic acid, polyglycolic acid, tricalcium phosphate, hydroxyapatite [27, 28]. Galler has investigated use of enzyme-cleavable hydrogel made from self-assembling peptide nanofibers to encapsulate dental pulp stem cells [29].

Hydrogels are networks of hydrophilic polymer chains. A process of polymer crosslinking within the gel produces a three-dimensional solid that maintains its integrity even in a high concentration of water. These materials are highly absorbent and possess a high degree of flexibility. Hydrogels have been utilized for many applications, including scaffold fabrication in tissue engineering [30], cell culturing 
[31], drug delivery systems [32], as well as environmental and industrial uses, amongst others. Many various types of materials exist for preparation of hydrogel scaffolds. These can be broadly classified as chemically cross-linked hydrogels, physical hydrogels, and nanocomposite hydrogels [23]. One of the polymers of natural origin is cellulose. A specific type of cellulose-based compound is methylcellulose.

Methylcellulose has been traditionally used as a food additive and has thermoreversable characteristics [33]. This material is a good candidate for being a tissue engineering scaffold due to its desirable mechanical properties, biocompatibility and cost-effectiveness. Hydrogel's stable properties make it an attractive material for use in regenerative endodontics, where the hydrogel serves a dual purpose of drug delivery vehicle, as well as a scaffold for pulpal tissue engineering. A successfully fabricated methylcellulose hydrogel scaffold could potentially serve as an alternative to the currently used calcium hydroxide.

\section{CONCLUSION}

The review of present literature shows that no irrigant, medicament or other therapeutic agent exists for use in non-surgical endodontic therapy or regenerative endodontics that meets all of the desired criteria of antibacterial properties, biocompatibility and successful patient outcomes. The search for such material and product continues and is the subject of research by many within the endodontic community.

\section{REFERENCES}

1. Ricucci, D., \& Siqueira Jr, J. F. (2010). Biofilms and apical periodontitis: study of prevalence and association with clinical and histopathologic findings. Journal of endodontics, 36(8), 1277-1288.

2. de Chevigny, C., Dao, T. T., Basrani, B. R., Marquis, V., Farzaneh, M., Abitbol, S., \& Friedman, S. (2008). Treatment outcome in endodontics: the Toronto study-phase 4: initial treatment. Journal of endodontics, 34(3), 258-263.

3. Sjögren, U. L. F., Hägglund, B., Sundqvist, G., \& Wing, K. (1990). Factors affecting the long-term results of endodontic treatment. Journal of endodontics, 16(10), 498-504.

4. Torabinejad, M., Handysides, R., Khademi, A. A., \& Bakland, L. K. (2002). Clinical implications of the smear layer in endodontics: a review. Oral Surgery, Oral Medicine, Oral Pathology, Oral Radiology, and Endodontology, 94(6), 658-666.

5. Johnson, W. T., \& Noblett, W. C. (2009). Cleaning and shaping. Torabinejad $\mathrm{M}$, Walton RE. Endodontics principles and practice. Saunders.

6. Reeh, E. S., \& Messer, H. H. (1989). Long- term paresthesia following inadvertent forcing of sodium hypochlorite through perforation in maxillary incisor. Dental Traumatology, 5(4), 200-203.
7. Siqueira Jr, J. F., Machado, A. G., Silveira, R. M., Lopes, H. P., \& De Uzeda, M. (1997). Evaluation of the effectiveness of sodium hypochlorite used with three irrigation methods in the elimination of Enterococcus faecalis from the root canal, in vitro. International endodontic journal, 30(4), 279282.

8. Sjögren, U., Figdor, D., Persson, S., \& Sundqvist, G. (1997). Influence of infection at the time of root filling on the outcome of endodontic treatment of teeth with apical periodontitis. International endodontic journal, 30(5), 297-306.

9. Sim, T. P. C., Knowles, J. C., Ng, Y. L., Shelton, J., \& Gulabivala, K. (2001). Effect of sodium hypochlorite on mechanical properties of dentine and tooth surface strain. International Endodontic Journal, 34(2), 120-132.

10. Shabahang, S., Torabinejad, M. (2003). Effect of MTAD on Enterococcus faecalis- contaminated root canals of extracted human teeth. Journal of Endodontics, 29(9):576-9.

11. Retamozo, B., Shabahang, S., Johnson, N., Aprecio, R.M., Torabinejad, M. (2010). Minimum contact time and concentration of sodium hypochlorite required to eliminate Enterococcus faecalis. Journal of Endodontics, 36(3):520-3.

12. McComb, D., Smith, D.C. (1975). A preliminary scanning electron microscopic study of root canals after endodontic procedures. Journal of endodontics, 1(7):238-42.

13. Sim, T.P., Knowles, J.C., Ng, Y.L., Shelton, J., Gulabivala, K. (2001). Effect of sodium hypochlorite on mechanical properties of dentine and tooth surface strain. International Endodontic Journal, 34(2):120-32.

14. Grigoratos, D., Knowles, J., Ng, Y. L., \& Gulabivala, K. (2001). Effect of exposing dentine to sodium hypochlorite and calcium hydroxide on its flexural strength and elastic modulus. International endodontic journal, 34(2), 113-119.

15. Jenkins, S., Addy, M., \& Wade, W. (1988). The mechanism of action of chlorhexidine: a study of plaque growth on enamel inserts in vivo. Journal of clinical periodontology, 15(7), 415-424.

16. Estrela, C., Silva, J.A., Alencar, A.H., Leles, C.R., Decurcio, D.A. (208). Efficacy of sodium hypochlorite and chlorhexidine against Enterococcus faecalis: a systematic review. Journal of Applied Oral Science, 16(6):364-8.

17. Shabahang, S., Aslanyan, J., Torabinejad, M. (2008). The substitution of chlorhexidine for doxycycline in MTAD: the antibacterial efficacy against a strain of Enterococcus faecalis. Journal of endodontics, 1;34(3):288-90.

18. Basrani, B. R., Manek, S., Sodhi, R. N., Fillery, E., \& Manzur, A. (2007). Interaction between sodium hypochlorite and chlorhexidine gluconate. Journal of endodontics, 33(8), 966-969. 
19. Torabinejad, M., Shabahang, S., Kettering, J., \& Aprecio, R. (2003). Effect of MTAD on E Faecalis: an in vitro investigation. J Endod, 29, 400-3.

20. Nair, P. N. R. (2006). On the causes of persistent apical periodontitis: a review. International endodontic journal, 39(4), 249-281.

21. Sathorn, C., Parashos, P., \& Messer, H. H. (2005). Effectiveness of single- versus multiple- visit endodontic treatment of teeth with apical periodontitis: a systematic review and metaanalysis. International Endodontic Journal, 38(6), 347-355.

22. Weiger, R., Hitzler, S., Hermle, G., \& Löst, C. (1997). Periapical status, quality of root canal fillings and estimated endodontic treatment needs in an urban German population. Dental Traumatology, 13(2), 69-74.

23. O'brien, F. J. (2011). Biomaterials \& scaffolds for tissue engineering. Materials today, 14(3), 88-95.

24. Bohl, K. S., Shon, J., Rutherford, B., \& Mooney, D. J. (1998). Role of synthetic extracellular matrix in development of engineered dental pulp. Journal of Biomaterials Science, Polymer Edition, 9(7), 749-764.

25. Banchs, F., \& Trope, M. (2004). Revascularization of immature permanent teeth with apical periodontitis: new treatment protocol?. Journal of endodontics, 30(4), 196-200.

26. Torabinejad, M., \& Turman, M. (2011). Revitalization of tooth with necrotic pulp and open apex by using platelet-rich plasma: a case report. Journal of endodontics, 37(2), 265-268.

27. Gotlieb, E. L., Murray, P. E., Namerow, K. N., Kuttler, S., \& Garcia-Godoy, F. (2008). An ultrastructural investigation of tissue-engineered pulp constructs implanted within endodontically treated teeth. The Journal of the American dental association, 139(4), 457-465.

28. Chandrahasa, S., Murray, P. E., \& Namerow, K. N. (2011). Proliferation of mature ex vivo human dental pulp using tissue engineering scaffolds. Journal of endodontics,37(9), 12361239.

29. Galler, K. M., Hartgerink, J. D., Cavender, A. C., Schmalz, G., \& D'Souza, R. N. (2012). A customized self-assembling peptide hydrogel for dental pulp tissue engineering. Tissue Engineering Part A, 18(1-2), 176-184.

30. Mellati, A., Dai, S., Bi, J., Jin, B., \& Zhang, H. (2014). A biodegradable thermosensitive hydrogel with tuneable properties for mimicking threedimensional microenvironments of stem cells. Rsc Advances, 4(109), 63951-63961.

31. Discher, D. E., Janmey, P., \& Wang, Y. L. (2005). Tissue cells feel and respond to the stiffness of their substrate. Science, 310(5751), 1139-1143.

32. Pandey, S., Mewada, A., Thakur, M., Tank, A., \& Sharon, M. (2013). Cysteamine hydrochloride protected carbon dots as a vehicle for the efficient release of the anti-schizophrenic drug haloperidol. RSC advances, 3(48), 26290-26296.

33. Martin, B.C., Minner, E.J., Wiseman, S.L., Klank, R.L., Gilbert, R.J. (2008). Agarose and methylcellulose hydrogel blends for nerve regeneration applications. Journal of neural engineering, 5(2):221. 